\title{
Measures to Increase Local Food Supply in the Context of European Framework Scenarios for the Agri-Food Sector
}

\author{
Ariane Voglhuber-Slavinsky ${ }^{1,2, * \mathbb{D}}$, Hartmut Derler ${ }^{3} \mathbb{D}$, Björn Moller $^{1}$, Ewa Dönitz ${ }^{1}$, Enno Bahrs ${ }^{2} \mathbb{D}$ \\ and Simon Berner ${ }^{3}$
}

1 Competence Center Foresight, Fraunhofer Institute for Systems and Innovation Research ISI, Breslauer Straße 48, 76139 Karlsruhe, Germany; Bjoern.Moller@isi.fraunhofer.de (B.M.); Ewa.Doenitz@isi.fraunhofer.de (E.D.)

2 Institute of Farm Management, University of Hohenheim, Schwerzstraße 44, 70599 Stuttgart, Germany; bahrs@uni-hohenheim.de

3 Institute of Applied Production Sciences, Sustainable Food Management, University of Applied Sciences FH Joanneum, Eggenberger Allee 11, 8020 Graz, Austria; hartmut.derler@fh-joanneum.at (H.D.); simon.berner@fh-joanneum.at (S.B.)

* Correspondence: ariane.voglhuber-slavinsky@isi.fraunhofer.de

Citation: Voglhuber-Slavinsky, A.; Derler, H.; Moller, B.; Dönitz, E.; Bahrs, E.; Berner, S. Measures to Increase Local Food Supply in the Context of European Framework Scenarios for the Agri-Food Sector. Sustainability 2021, 13, 10019. https:/ / doi.org/10.3390/su131810019

Academic Editor: Alessandra Durazzo

Received: 14 July 2021

Accepted: 17 August 2021

Published: 7 September 2021

Publisher's Note: MDPI stays neutral with regard to jurisdictional claims in published maps and institutional affiliations.

Copyright: (c) 2021 by the authors. Licensee MDPI, Basel, Switzerland. This article is an open access article distributed under the terms and conditions of the Creative Commons Attribution (CC BY) license (https:// creativecommons.org/licenses/by/ $4.0 /)$.

\begin{abstract}
The issue of local food supply has attracted considerable political and public attention, due to the changing preferences of consumers, who have more awareness about ecological sustainability, in particular, but also due to recent developments concerning the COVID-19 pandemic. In order to identify measures facilitating local food value chains, which are resilient to different nationwide and global future developments, the aim of our analysis was to set the identified measures derived from the local roadmap of the city of Graz in the context of European scenarios for the agri-food sector in 2035. The results show that certain measures are applicable under all of the described scenarios, such as the food policy council, whereas some measures-for example, open food labs-are less suitable or need to be adjusted to fit the purpose within changing framework conditions. Setting specific measures for a city region in the broader context of European agri-food scenarios provides a systemic perspective, thus making the multiple links and influences more visible.
\end{abstract}

Keywords: robustness check; food system; foresight; qualitative scenarios; roadmaps

\section{Introduction}

The future food system must produce more food on less land while, at the same time, contributing to a carbon-neutral future (e.g., towards the $1.5^{\circ} \mathrm{C}$ goal). Moreover, social factors, such as food security, food waste, and an aging population, already impose pressures on the current and future food system [1]. Therefore, in recent years, several strategies and concepts have been developed to feed more than 10 billion people by 2050, such as sustainable intensification [2], circular food systems [3], and sustainable food systems [4]. What these strategies and concepts have in common is that they foresee radical transformations, transitions, or regime shifts of the food system toward ecologically, socially, and economically sound food provision $[5,6]$. One approach which has been discussed is the creation of local food systems to meet many of the above challenges.

The COVID-19 pandemic has caused disruptions in global food supply networks and highlighted the role of local food systems [7-9]. Thilmany et al. [10] put up for discussion the long-lasting effect that "COVID-19 may lead policy-makers to evaluate and refine the incentives and barriers current policies and regulations represent to" local and regional food systems. Certainly, more research will be conducted in the coming years, in order to prove the resilience of local and regional food systems [10], as well as to identify the optimum spatial coverage of such systems [11].

Promoting local food supply can lead to more resilient food systems, if the comparative advantages of the respective site are leveraged. On one hand, locally adapted cultivars 
can enhance the productivity of the site, compared with monocultures, while on the other hand, they can contribute to more diversified food for the population [12]. However, the cultivation of local fruits and vegetables can imply seasonal fluctuations in the availability of food. Local food systems with more crop rotation-and, thus, diversification - can go hand-in-hand with the ecologization of agricultural production, which can be beneficial, for example, for the conservation, promotion, and enhancement of biodiversity. In addition, "the majority of global micronutrients [...] and proteins [...] are also produced in more diverse agricultural landscapes" [13]. As highlighted in the Farm to Fork Strategy, the whole food value chain should be in focus within the transition toward a sustainable food system [14].

This paper focuses on the interaction of local food systems in a global environment. Local food supply can enhance the resilience and adaptive capacity of food systems and food value chains. However, at the same time, the respective share of the local products determines the sustainability of the food system. There are products that can be produced more efficiently on a global level, where the transport savings do not outweigh more input of land or productivity losses, if produced locally [15-17]. In contrast, when considering other dimensions of the food system, such as biodiversity or the distribution of added value, local production can outperform global production [18]. Moreover, local food networks can "[ ... ] increase local food security by having food more reliably available where it is needed and by contributing to local resilience through community economic development" [19]. Considering the mere quantities of food produced, a world without trade would result in a lower total amount of available food due to yield differences [20]. Furthermore, Kissinger et al. [21] have analyzed the environmental impact of local food production, comparing land, water, carbon, and ecological footprints for Southwest British Columbia (Canada). They found that a biophysical advantage of locally cultivated food could only be found for some commodities, based on the current food system relying on a non-renewable energy supply [21].

The main objective of this study is to investigate the robustness and applicability of measures to regionalize food supply in a test region within the future developments of European agri-food scenarios, as defined by expert groups. Therefore, we investigated measures (see Section 4.1) for a more local food system, within the context of future framework scenarios. Our research objective is to explore whether the defined measures withstand different future developments, and which measures prove to be the most favorable with regard to their viability and robustness. Previous research focused on single technological innovations and scenarios has been elaborated in distinct research studies [22-27]. However, to the best of our knowledge, the combination of scenarios and road mapping from two different studies has not yet been described in the literature.

The local measures from the roadmap of the region of Graz [28] and the framework scenarios from the European project FOX—Food processing in a box [29]—can be classified as foresight methods. According to the OECD-EC definition of cities in Europe, half of the 828 identified cities in the EU, Switzerland, Iceland, and Norway have an urban center larger than 50,000 inhabitants, with 341 falling in the range of 100,000 to 500,000 inhabitants [30]. In the year 2011, Graz had a population of about 260,000 inhabitants and, therefore, serves as a good example of a European city, considering its size. The purchasing power parity of Austria is above average, at the European scale [31]. When considering the regional level, Styria is average, compared to other German and Austrian regions [32]. The project Smart Food Grid Graz (SFGG), providing local measures, deals with the formation of more local food value chains serving various goals [28], such as a reduction in $\mathrm{CO}_{2}$ emissions due to shorter transport distances [33,34], the promotion of the local economy, and strengthening of rural areas, as well as the provision of fresh and diverse food [35,36]. The EU defines local food systems as systems where production, processing, and retail take place within a defined geographical area, and by the closeness of social relationships between the producer and consumer [37]. Although this definition has been supported by other authors [38-40], the term depends on the characteristics of 
the local area, such as urban or rural structure [37]. The European project FOX provides a scenario analysis to demonstrate the outcomes of different likely developments for the year 2035, as a tool for strategy development and informed decision making to gain future literacy [29]. Both projects-SFGG and FOX-are explained in further detail in Section 4. The actual focus of this paper, the combination of the two approaches, is presented in Section 5 .

The remainder of this paper is organized as follows: In Section 2, an overview of the agri-food system is provided and the terms within are defined. Section 3 describes the methodological approach of these two projects, as well as their combination. Section 4 gives an overview of the main results of these two projects and explains the content of the respective projects in more detail. Section 5 presents the results of the combination and an expert-based assessment of the measures in the scenarios. In Section 6, the advantages and the limitations of the study are discussed, followed by a concluding outlook in Section 7.

\section{The Agri-Food System}

For a better understanding of the different terms within the agri-food system, Figure 1 provides an overview of the elements and their relationships. Although, in the literature, the terms "supply chain" and "value chain" are often used interchangeably, we distinguish their use in this study. The concept of the value chain is applied throughout the article to visualize the affected stages of the value chain, as well as to prove the completeness of the presented topics.

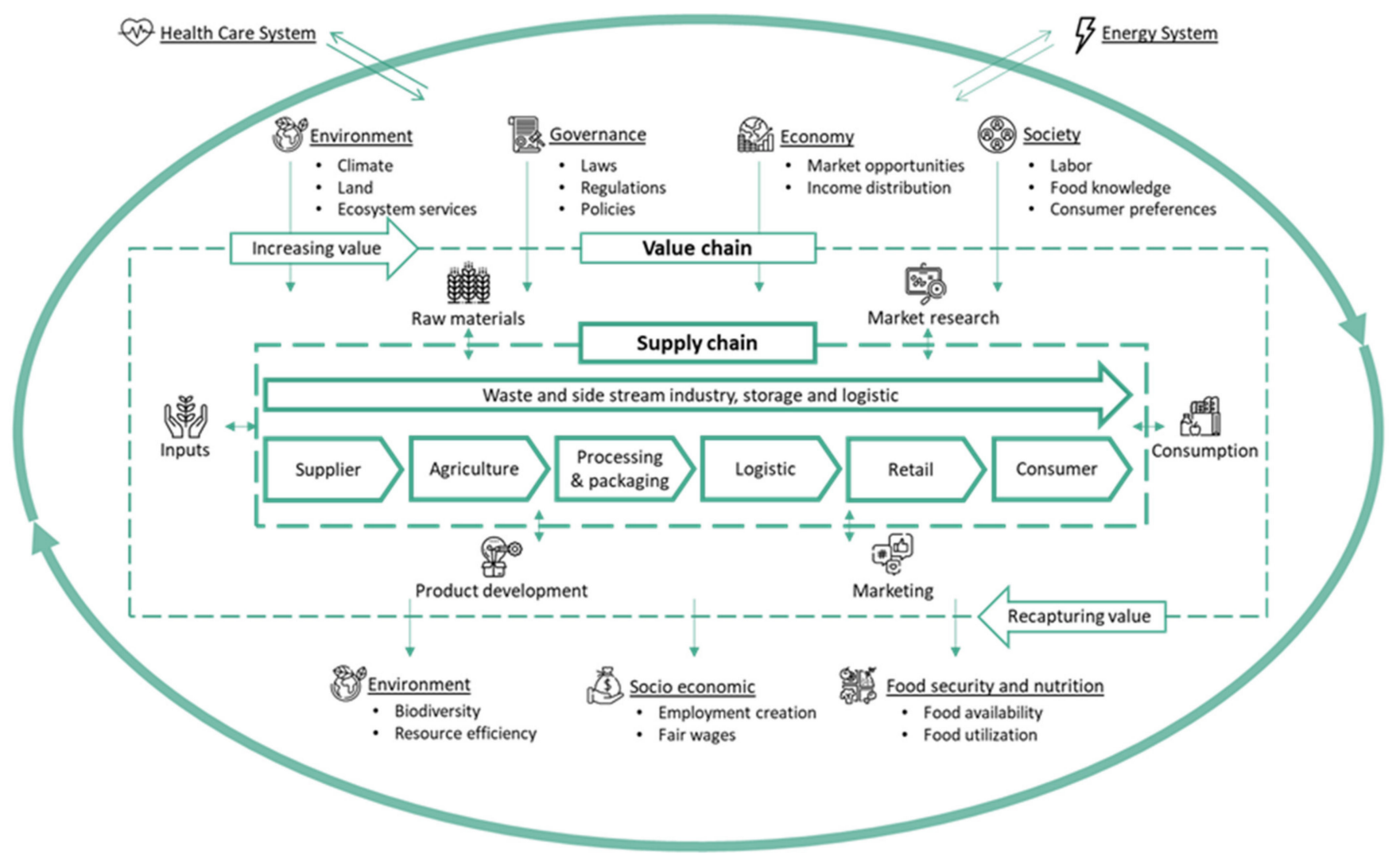

Figure 1. Model of the agri-food system.

The agri-food system can be defined as the complete set of elements and activities involved in producing, distributing, and consuming food, and the impacts of these activities with regard to environmental and socio-economic factors, as well as food security and nutrition [41-43]. Gaitán-Cremaschi et al. [44] described it as a "network of actors and activities that interact with one another, within an ecological, social, political/cultural, and economic environment". The various feedback mechanisms in the agri-food system operate 
at multiple levels, in terms of time and scope, while providing nourishment and sustaining health [45]. Important drivers within the food system are the environment, governance, economy, and societal aspects. The agri-food system is in constant exchange with other systems, such as the energy system or the health sector [42,44]. The whole agri-food system is integrated in a societal context, as well as the natural environment; influenced and affected by climate, resources such as water and land, as well as ecosystems and genetics [42,46]. It relies on ecosystem services and affects biodiversity by its encroachment on natural habitats [47]. On one hand, the environment is a driver in the agri-food system, providing ecosystem services or climatic conditions influencing agricultural production. On the other hand, the environment is impacted by the agri-food system. The resources utilized within the value-creating activities can be used in a more or less efficient way, or the biodiversity will be impacted directly by the type of agricultural management.

The terms "value chain" and "supply chain" in the agri-food system are not clearly differentiated. One possible distinction is that agri-food "value chain studies focus more on value appropriation by actors throughout the chain", while the term supply chain is more often used for the management of raw material supply, production, processing, logistics, and distribution [48]. We include the consumer, as proposed by Bukeviciute et al. [49], and do not follow definitions where the last step in the supply chain is the distributor and retailer $[48,50]$. In addition, the value chain captures non-physical activities, such as marketing or product development. It was developed by Michal Porter and can be described as "a tool to understand how firms can create and sustain value for their customers and how maximize it, so the Value Chain then becomes the source of competitive advantage" [51]. Mausch et al. [45] described the value chain as an analytical framework serving to identify the position and the linkages between actors, as well as to locate the distribution of added value.

The first stage of the supply chain includes supplier activities relating to feed, fertilizer, or plant protection. The agricultural sector comprises crop production and the raising of livestock, forestry, fisheries, and aquaculture [49,52]. As the output of agricultural production is diverse, there are many distribution channels. The different products are sold and transferred to wholesalers, the food processing industry, or even directly to retailers or final consumers. Mostly, the products are processed in successive stages, packaged, and dispatched to customers. Toward the end of the supply chain, the final distribution of products takes place. Influencing factors in distribution include "transportation infrastructure, trade regulations, government transfer programs, and storage requirements" [43]. In addition to selling products, retailers, as the penultimate step within the supply chain, may also carry out food services such as take-away meals or catering services. Waste and side-stream industries, as well as storage, are considered throughout the whole agri-food supply chain. The last element of the supply chain is the consumption stage. Prices and income levels, as well as cultural traditions or preferences, social values, education, and health status influence consumption. The decision of what to eat is additionally affected by advertising and the structure of the chain [43].

Extended value is created through the provision of inputs and services to support the flow of goods through the different stages of the value chain [53]. A sustainable agri-food value chain should be profitable throughout all its stages, have broad-based benefits for society, and should not permanently deplete natural resources [52]. As value chains are dynamic, governance is included as a central point. Governments, non-governmental organizations (NGOs), and regulatory authorities are responsible for monitoring and regulating the value chain [54].

\section{Methods and Background}

In this section, the method of the article is described. Furthermore, information about the methodologies used in the previous studies is provided. 


\subsection{Method of This Study: Setting the Measures in the Context of Scenarios}

The aim of this research was to assess the robustness and applicability of local measures to regionalize the food supply within the framework of European agri-food scenarios. We used results from two foresight studies, each addressing different foresight dimensions. One research project developed measures to increase the local food supply in a target region. The other research project built scenarios for the European agri-food sector. The measures are locally designed for a defined future, while the scenarios are at the European level and describe different variants of future developments. The scenarios in the latter research project were used to assess how the measures defined in the first research project perform under the European scenarios. To allow for assessment of these two aspects, we defined the viability and robustness of the measures. In a workshop including experts from both preliminary projects, the measures developed within the road map were discussed, in terms of their applicability in the European scenarios. The leading question was: "To what extent might a measure be implemented against the background of the European scenarios?" Evaluation scales were used to quantitatively measure the opinions of experts; in this case, a scale ranging from -2 to +2 was used. Each scale point was provided with a verbal designation; for example, -2 meant that the measure was not probable to be successful in the scenario, 0 meant that the measure was rather neutral and was neither supported nor hindered by the framework conditions in the scenario, and +2 stood for a very supportive environment in the scenario for the corresponding measure. A measure was defined as viable when it was applicable to at least one scenario, while a measure was robust when applicable to more than one scenario. After this assessment, we used a narrative approach to discuss the implications of the scenarios and the measures.

This section provides a description of the methodology applied in the SFGG project, where the measures to enhance local food supply evolved [28]. Furthermore, the scenario approach used in the project FOX is described [29], as well as the methodological combination of the two foresight approaches, which is the main focus of this article. To perform the latter, information from the previous foresight researches was used.

The two approaches described below $[28,29]$ were combined, in order to set the local perspective in a global context, by testing the applicability of the measures under the three scenarios, which is the main focus of the present article. In scenario-based road mapping approaches, the scenarios and the road map were developed in the same joint project [22-24,27]. Hussain et al. [25] stated that the scenarios in scenario-based road mapping are often not exploratory in nature. They propose to build the scenarios first, after which the "roadmap is [...] developed based on the resulting scenarios" [25]. We used the results of distinct, existing projects to derive implications for the robustness of measures under different framework conditions. This enabled us to amend current studies while, at the same time, our scenarios and our method are applicable to other regions with a road mapping or similar approach integrating different measures. Furthermore, we did not concentrate on the market or corporate level and on technological road mapping, as other studies have [24-27] but, instead, on the system level without a concrete technological focus.

\subsection{Background on the Methodology of the Previous Research}

In this section, the background of the previous studies is explained. The previous studies were conducted in 2017/2018, in the case of the SFFG project [28], and 2019/2020, in the case of the FOX project [29].

\subsubsection{Roadmap Presenting the Local Measures}

Six measures (see Section 4.1) comprise the core elements of the road map developed within the previous foresight project, Smart Food Grid Graz (SFGG), with the aim to enhance a local food supply of the Austrian city region Graz. Road mapping constitutes a flexible planning method to analyze and structure relations between markets, products, and technologies over time [55]. In previous years, road mapping has also been used to 
analyze and understand the environmental landscape of systems, as well as to map the transitions of systems toward a specific goal [56-58]. Roadmaps are usually oriented to the following three questions: (1) Where do we want to go?; (2) where are we now?; and (3) how can we get there? [59].

A stakeholder process was introduced, guided by the normative goal "by 2030, 30 percent of the food consumed in the target area should originate from the target area". The figure if $30 \%$ was calculated based on the weight of the products. This goal was chosen as it was considered realistic and easy to communicate to stakeholders [28]. This process was divided into three stages, which were conducted in the run-up to this study. In the first stage, the purpose and frame of the roadmap was defined (e.g., the normative goal). The second stage included a thorough analysis of the target food system, including stakeholder interviews and the calculation of self-sufficiency rates of basic food items. In workshops, these data were used to synthesize and map measures onto a roadmap. In the third stage, the results of the road mapping approach were communicated to a broader audience, and follow-up activities with the city council of Graz were initiated [28].

In contrast to the scenarios, describing different possible and consistent future framework conditions (see Section 3.2.), this roadmap follows one desired picture of the future.

\subsubsection{Scenarios for the European Food Sector}

The scenarios for the European food sector, elaborated in a previous foresight study, served as the framework to set the local measures into a bigger context, with the intent to proof these measures against developments described for the future European food sector. The scenarios were developed for the year 2035, and describe developments along the entire value chain. The applied scenario method enables a structured examination of different developments and helps to prepare involved players to act in a future-oriented way. It is a widely used method in foresight, which can be applied to different topics [60-67]. The process of scenario creation supports the understanding of complex systems and helps to handle uncertainty [68]. A wide range of intuitive (qualitative) and algorithmic (quantitative) scenario approaches can be distinguished [69]. A qualitative method was used in the study considering the European food sector in 2035, building on the plausibility and explanation of the connections and relationships among the different factors and their future assumptions [70,71]. Furthermore, in this paper, static scenarios are developed, which consider a fixed point in time in the future [61]. As a starting point, a trend analysis was conducted, which identified the most important factors influencing the food sector from a bigger set of visible signals, movements, and developments [72]. Afterwards, the most important factors influencing the system - that is, the key factors-were identified. For these so-called driving forces, different development options in the year 2035 were derived, known as future assumptions. In the following, the future assumptions were reassembled into consistent and plausible descriptions of the future, as possible alternatives to one another [73]. Afterwards, in the study regarding the European food sector, expert opinions (13 external experts and participants from the consortium of the project FOX) were gathered in an online scenario-process, in order to augment the scenarios with further key factors and their future assumptions (for the detailed approach, see [29]). Nineteen experts involved in policy, industry, and science connected to the various levels of the agri-food sector contributed to the online consultation. These two steps were combined to develop three final scenarios. The transparent documentation of assumptions and the involvement of relevant actors ensured the generation of scenarios in a methodically comprehensible manner [67]. The created scenarios are neither best- or worst-case scenarios, nor an extrapolation of the current situation. Rather, they comprise significant changes from the present situation. Storytelling, as the last step, facilitated the communication of the scenarios, through comprehensible description of the different future developments [74,75].

In Table 1, an overview of the foresight approaches used to derive robust measures for the formation of more local agri-food value chains is provided. 
Table 1. The two foresight approaches used to derive future-proof measures.

\begin{tabular}{ccc}
\hline & SFGG (Smart Food Grid Graz) & FOX (Food Processing in a Box) \\
\hline Spatial coverage & Local & European \\
Time coverage & 2030 & $\begin{array}{c}\text { Expert consultation, online process with } \\
\text { international experts } \\
\text { Type of stakeholder engagement }\end{array}$ \\
Number of stakeholders involved & Local actors and stakeholders & 13 external experts and 25 institutions \\
within the FOX consortium & Three alternative scenarios \\
\hline
\end{tabular}

\section{Previous Foresight Studies: Local Roadmap and Framework Scenarios}

In the following, the projects SFGG [28] and FOX [29] are described in more detail. The backgrounds of these two projects and their results relevant to the approach provided within this study are presented. This sets the baseline for Section 5, where the two approaches are combined to derive robust measures.

\subsection{Measures in the Local Roadmap}

Six measures resulted from the road mapping process. "Food Dialogues" were introduced as a measure to link food actors from the target area with each other. It is understood as a participatory instrument, facilitating the exchange between the different agri-food actors such as local food producers, distributers, retailers, consumers, and authorities. These dialogs represent socio-economic, intellectual, and political spaces. Such spaces, where actors can share the debate on food topics, play an important role in the establishment of sustainable food systems [76].

In addition, we found that these dialogues should be supported by a local "Food Policy Council" (FPC) [28]. In the literature, FPCs are described as a democratic instrument to manage food issues at different scales [77]. Usually, they are constituted by a group of representatives from different food stakeholder groups, such as farmers, government officials, business people, and members of NGOs. Several actions were discussed, which an FPC could initiate to achieve the normative goal mentioned above. For instance, an FPC could address food in local spatial plans (e.g., the conservation of land in peri-urban areas for food production to counteract an ongoing loss of arable land), adapt food procurement strategies in the favor of local food products, and link food activities with activities in other fields (e.g., smart cities, climate plans). These issues have not been addressed sufficiently in the case study area [28].

The "Market Basket for Local Food" has been introduced to address several dimensions. It is based on the idea that a food basket of locally available food products should be defined, which is in accordance with the national food pyramid, and changes with seasonal constraints. Based on the given food categories of the food pyramid, the basket can monitor the availability and prices of the respective food products. Thus, it considers two dimensions: First, it serves as an information source for consumers regarding the currently available food products for each food category. Second, it serves as a monitoring scheme for stakeholders to track down the local food streams. For instance, this can help canteen kitchen chefs to identify whether they can use more local products in their meals, as the measure allows them to check the current availability and prices of the respective food products.

Another measure is called "Online Metafinder". It can be understood as an independent instrument (e.g., hosted by a local public authority) which allows actors (e.g., business to consumers, business to business) to receive a comprehensive overview of the local food products offered in web shops in the target area. The metafinder supports actors to compile a market basket based on their individual preferences. It is supported with additional information on the food products, such as their origin and the indication of specific food qualities (e.g., organic or conventionally produced). 
Small-scale farmers tend to lack the economic resources and knowledge needed to diversify their businesses. At the same time, the development of food products and the direct marketing of these can represent a meaningful income stream for peasant farmers. "Open Food Labs" have been stated as a measure to address this issue. Open Food Labs focus on the research and development of novel food products, plants, or processes. As such, they can reveal an entrepreneurial spirit, and foster the experimentation and innovation skills of farmers [78]. When co-creative elements are introduced in Open Food Labs, they can serve as an innovation incubator in the target area.

Finally, "Farmer Markets 2.0" represents an up-scaled version of traditional farmer markets. The measure was defined as a reaction to changing consumer demands. Several dimensions have been highlighted to transform traditional farmer's markets. For instance, they should be modified, in terms of logistics (e.g., the installation of pick-up box systems can allow consumers to buy local foods at any time). Furthermore, additional infrastructure, such as storerooms, spaces for workshops, and food processing facilities, can diversify the function of farmer markets from pure direct marketing to multi-functional places (e.g., farmers could offer workshops to consumers).

The six measures from the road mapping process were located within the food value chain, in order to visualize the addressed stages (see Figure 2). The measure "Food Dialogues" addresses the socio-economic, intellectual, and political dimensions within the food system. It is designed to bring together stakeholders from all the steps of the value chain. The local "Food Policy Council" (FPC) is understood as an institutionalized measure, which supplements the food dialogues. The FPC meets on a regular basis, with committed stakeholders from various steps along the value chain, with the aim to enable targeted interventions to address changes within the food system. Compared with the food dialogue, the outcome is more target-oriented toward a specific challenge within the food system and develops concrete actions. The "Market Basket for Local Food" targets the food production stage of the value chain, as well as the purchasing of food by consumers. To connect production and consumption, logistics have to be considered for this measure. The "Online Metafinder" addresses the retail stage, as well as consumers within the food system. It offers an overview of local products, from a diversity of online local food providers. This measure is considered to be hosted by local public authorities and, thus, the political dimension plays a major role. "Open Food Labs" corresponds to the production stage of the value chain and aims to offer farmers the opportunity to test ideas and develop new products in a secure environment. "Farmer Markets 2.0" addresses the retail and consumption stage of the value chain. It is considered as a new form of farmer's markets, including smart logistics and social activities that allow for engaging consumers with producers (e.g., through workshops).

\subsection{Framework Scenarios}

The scenarios for the European food sector in 2035 [29] serve as the framework in this study, which originated from the foresight process described in Section 3.2. In the following, three scenarios are presented, according to the publication by Moller et al. [29]. This assists in understanding the positioning of the local measures in the different scenarios, as presented in Section 5. The scenarios describe possible future situations where local measures from the SFGG are confronted under different framework conditions. Figure 3 presents the main characteristics of the scenarios, according to the stages of the value chain, indicating the comprehensive nature of these scenarios. 


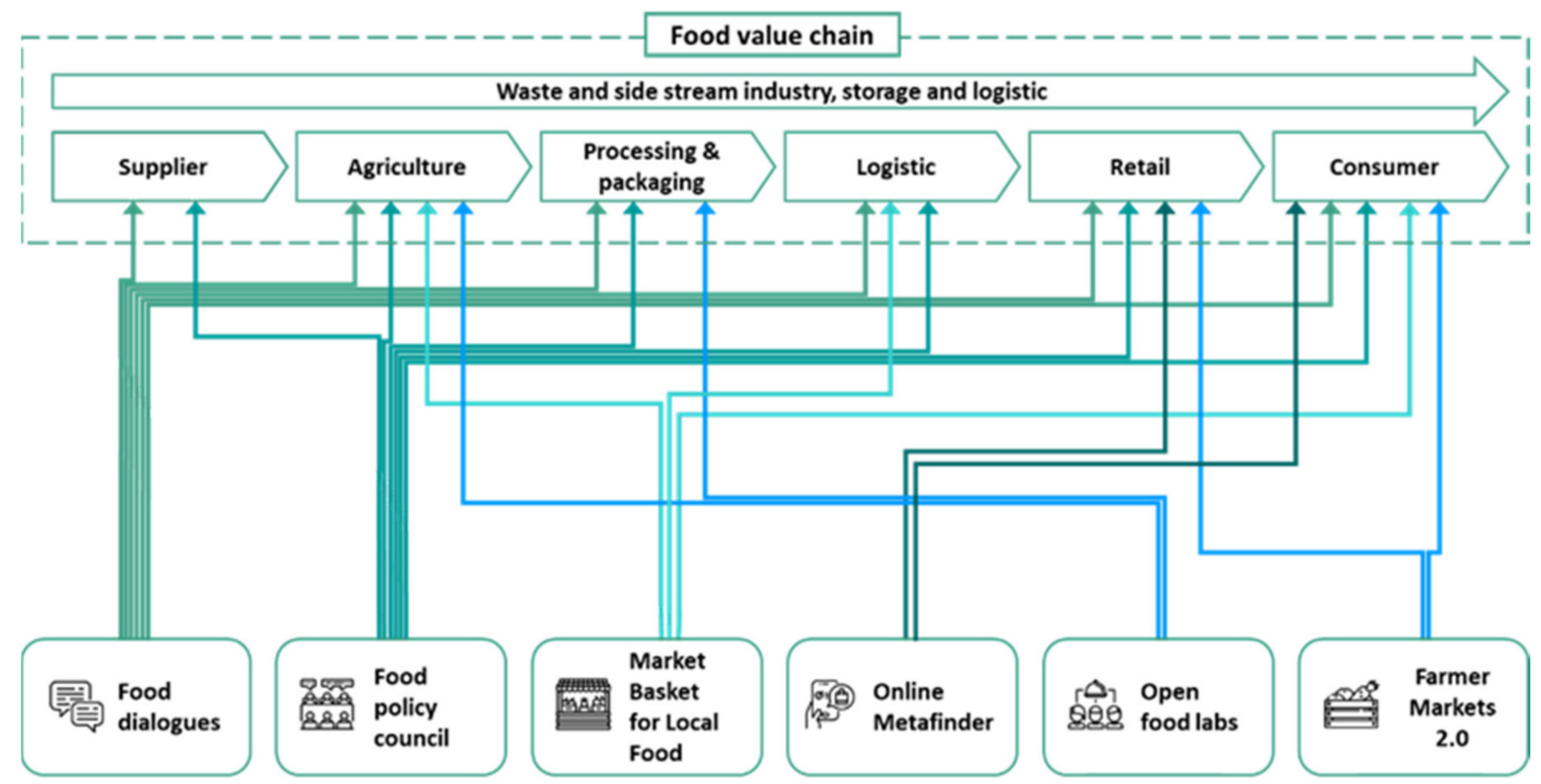

Figure 2. Measures in the local roadmap, with their allocation to the stages of the food value chain.

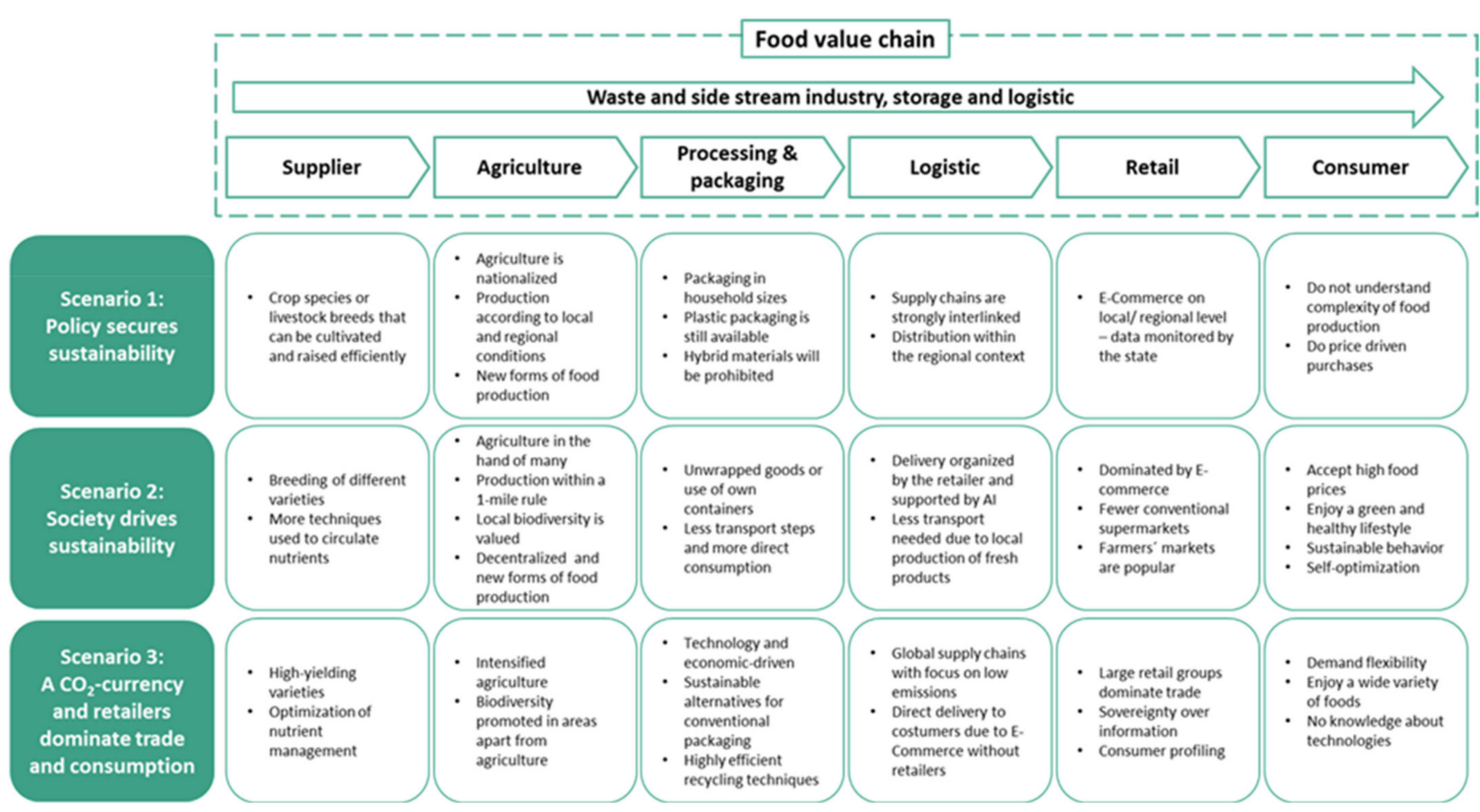

Figure 3. Framework scenarios for the European Food Sector in 2035.

4.2.1. Scenario 1: "Policy Secures Sustainability—Welfare States Centrally Ensure National Food Security"

Agriculture is increasingly being nationalized, in order to ensure that it serves the common good and gives every citizen access to sustainable, nutritious food. National states or even bigger regions wish to achieve more agricultural independence and, therefore, focus on crop species or livestock breeds that are suitable for local conditions. Consumers have great confidence in their government and are not concerned with the complexity of food production and its interaction with the environment. Sustainability is promoted, on the consumer side, through tax relief for fair and environmentally friendly products. In addition, agricultural production is intensively regulated (e.g., in terms of land and 
pesticide use, water consumption, or soil treatment). Politicians have recognized that sustainable agriculture is vital to national food security.

Encouraging its citizens to adopt a healthy lifestyle and promoting sustainable food trade and consumption (e.g., through locally implemented e-commerce) are key tasks of the state. Consumer profiles and food consumption instructions are often created, based on government-monitored e-health data, and are made possible through the data sovereignty of the state. The freedom of choice of citizens is restricted, but the major problem of food waste is effectively addressed by intelligently analyzing people's purchasing behavior and by legally banning food waste along the entire value chain.

The consumer's choice of food is mainly determined by price. Aspects such as sustainable production, fair trade, traceability, nutritional value, or local origin are considered secondary. Labels are less important in the food sector and, consequently, there will be very few. Economic growth is still the political objective, but only to the extent that resources are used responsibly and with care. The government, who decides how land, water, and energy should be used, manages them. Globalization tendencies are no longer relevant in the food sector. However, global tensions may arise due to resource scarcity in many parts of the world, which are problematic for production and food security. High production and food standards in the European Union pose an additional trade barrier, further reducing the choice of food.

Food diversity depends, to a great extent, on the local climatic conditions. Technologies such as indoor farming or the cultivation of meat are considered as useful supplements, but only if they are highly efficient. Digital technologies serve to better control the entire complex value chain and the centralized supply of basic foodstuffs can be supported by efficient logistics.

Internalization of social and environmental costs does not take place, and these costs have to be paid subsequently with public funds. Short-term regulatory interventions become necessary to comply with EU requirements and to limit negative effects reactively. Food prices remain low, companies are not incentivized to reduce external costs, and agriculture delivers low-cost substrates to the bio-economy industry.

Environmental and climate policy in agriculture are regulated by law, with regulations or penalties for non-compliance. To secure the economic existence of farms, compensation is paid to protect European agriculture from foreign trade. Interventions such as, for example, the rewetting of peatlands for climate protection reasons are also well-compensated, according to the standard land value.

\subsubsection{Scenario 2: "Society Drives Sustainability—Consumers Enjoy a Green and Healthy Lifestyle"}

People who voluntarily change their habits in order to protect nature drive the change in consumer behavior. A healthy lifestyle, sustainable behavior, and increased awareness of high-quality food are crucial for a large part of society. Excessive economic growth, disregarding social injustice, and environmental damage are identified as key problems, and "the post-growth society" is moving away from consumerism. Availability and a sustainable food value chain are essential for food consumption patterns. The driving forces do not emanate from the national state, but there is still a well-organized government at the local level. Consumers are skeptical about globalized food trade, due to a lack of information about production conditions and negative environmental impacts. They prefer local or regional products and avoid imported exotic foods.

In everyday life, a mindful use of resources takes place, as people are aware of their scarcity. A high level of self-sufficiency in food production is pursued, but solidarity is still shown toward regions with unfavorable production conditions. Energy supply is largely decentralized and privatized. Consumers accept high food prices, as long as the production is local and organic. As a result, sustainable production is made possible and people take the initiative by growing their own fruits and vegetables.

Agricultural land is in the hands of many and a high amount of food, especially fresh food, is produced within a 1-mile radius of the place of consumption. Agriculture 
enjoys great trust in society, due to the vicinity and intensive contact between farmers and consumers. Local biodiversity does not suffer from food production. Staple foods that cannot be produced locally are still imported and, where feasible, replaced by local alternatives. Data availability and AI technologies make it easy to predict demand and to avoid food losses.

New digital technologies are used for smart decisions in single parts of the value chain. Consumers are very open to new technologies, but only if transparent information is available. They are even willing to pay more for products from, for example, urban farming, or for cultivated meat. Food is sustainable and efficiently supplied over digital platforms. In the well-organized food service system, all citizens can play a role. Decentralization and interconnectivity are possible, as data is property of the public.

Biodegradable or even edible food packaging are used to minimize waste. E-commerce stores are very popular and retailers organize the entire food logistics chain. Conventional supermarkets have been replaced by logistic centers, but fresh local food is still mostly bought at farmer's markets. Labelling of food is very important, but also specific to the local community or region.

The internalization of external costs leads to changes in consumption patterns and, subsequently, to the alteration of production. Environmental and social goals are agreed upon and quantified, in order to be able to monitor them. Both positive and negative effects are transparent for the entire agri-food system. A mix of instruments is implemented, including taxation, levies on imports at the EU borders, and minimum standards. This leads to increasing prices for numerous agricultural products as, at the same time, the input prices rise.

In principle, environmental and climate protection are achieved through the restructuring of consumption and production; however, where competitive disadvantages arise, regulatory intervention can provide compensation by granting subsidies.

4.2.3. Scenario 3: " $\mathrm{A} \mathrm{CO} 2$ Currency and Retailers Dominate Trade and Consumption-In a Globalized World, Markets and Technologies Ensure Prosperity for Top Performers"

Highly specialized global markets are widespread and global challenges are addressed by dynamic technological progress, instead of social change. The necessity to support the continuous growth of the economy is deeply rooted in society, leading to a very competitive environment. Big retail and sales groups, who dominate the food industry, are focused on maximizing their profit margins. E-commerce is very popular, and is mainly in the hands of the big box retailers. Consumers like to be flexible in their food choice.

Retailers have sovereignty over information and, thus, can design completely digitized value chains in their favor. Consumer buying behaviors, their preferences, and expectations are transparent, and they receive individual buying offers. The profiling of consumers is a core element of food service platforms. Food services are a leading industry in technological development and customer relations.

Intensified farming of huge, highly efficient monocultures has negative consequences for soils and biodiversity in these areas. The preservation of nature only takes place in designated areas, in order to compensate for the negative effects. The efficient production of food is a main priority, as supported by the majority of the population.

Due to the global food trade, consumers can enjoy a wide variety of foods. The price pressure is high, there are low-quality products in the food chain, and food safety cannot be guaranteed throughout complex value chains. The power of national and local governments is limited and over-ruled by multinational and supranational organizations, which also control resources such as land, water, and energy. Political standards are set to a minimum and vary from state to state. In the face of worsening climate change, international agreements can only be reached on a $\mathrm{CO}_{2}$ currency. Sustainable developments, such as combating biodiversity loss or climate change, are only a priority of multinational companies as long as they serve the aim of guaranteeing profits.

Retailers use sustainability as a business model and have recognized that offering sustainable products can strengthen their core business. Sustainability is priced into all 
products, in the form of a $\mathrm{CO}_{2}$ price. New digital solutions are helpful for consumers to choose products, and replace labels in the long-term. It is also possible to reduce food packaging to a minimum.

A circular economy is the new paradigm to follow, which is implanted by using side-streams of large-scale industrial food processes. Food losses are minimized, and scarce resources can be saved. Regardless of what is produced, predicting demand is fairly simple, due to $\mathrm{AI}$ and data availability.

Climate protection through $\mathrm{CO}_{2}$ trading is complemented by trading systems in other areas. For example, biodiversity trading is elaborated, incorporating contractual nature conservation and the provision of compensation areas. Additional trading schemes addressing water eutrophication or ocean acidification are implemented. However, all of these approaches are still under development; only $\mathrm{CO}_{2}$ trading is widespread.

Climate and environmental protection in agriculture is achieved through marketbased instruments and financial incentives. Environmental goods are priced, so either the consumption or the provision of environmental goods is connected to financial payments.

\section{Results}

In the following, the results of setting the measures in the context of the different scenarios are presented (see Figure 4). The results provide insights into which measures prove to be viable while being confronted with the different future developments. We refer to measures that may be applied to more than one scenario as robust measures. Therefore, the term robustness indicates that one measure is applicable in more than one scenario. The results are presented in three sections; one for each scenario. The evaluation scales were explained in detail in Section 3.1, and range from -2 (meaning that the measure was not probable to be successful in the current scenario) to +2 (indicating a high probability of success of the measure).
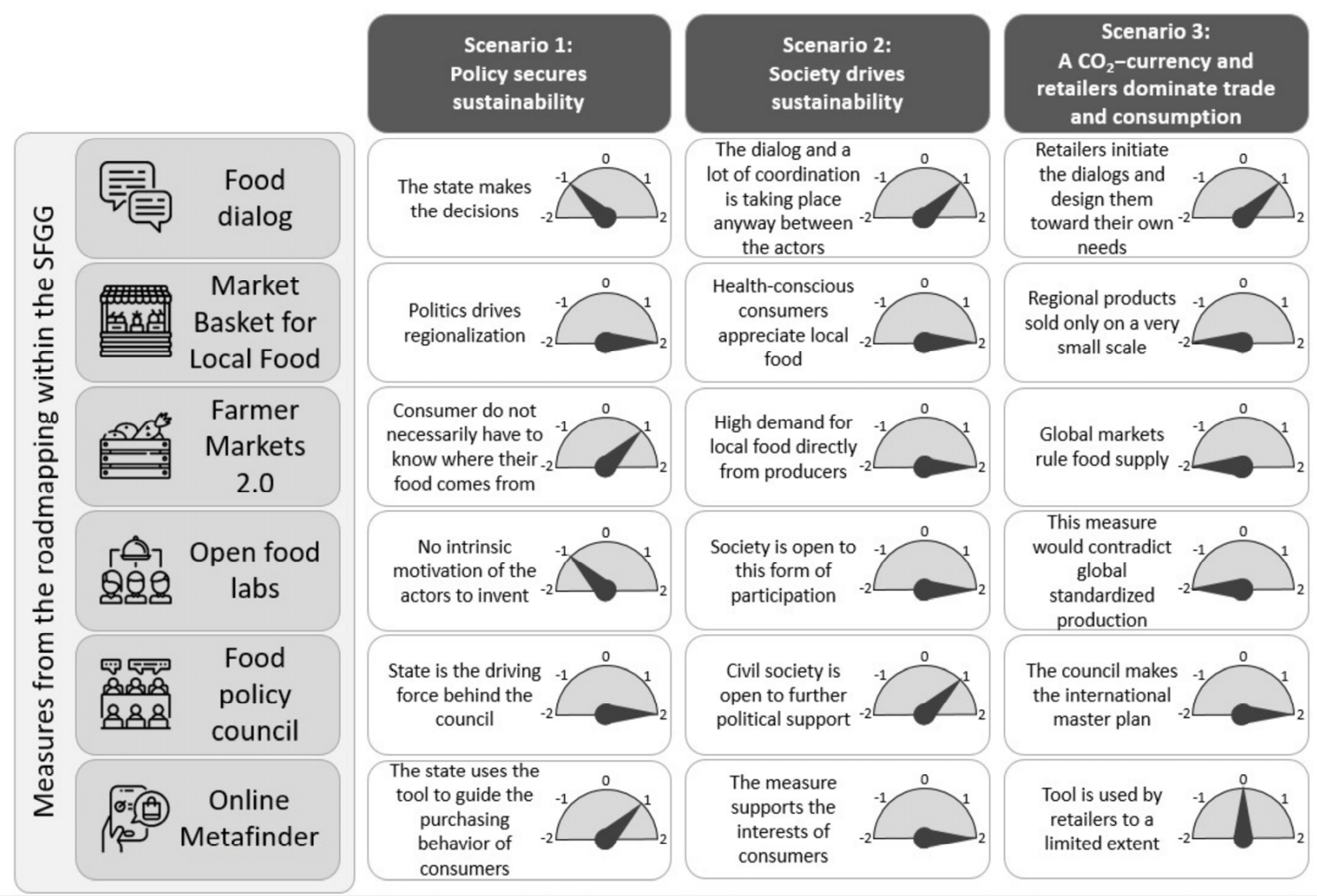

Figure 4. Viability check-measures from the road map within the project SFGG, in light of the different scenarios from the FOX project. 


\subsection{Scenario 1: Policy Secures Sustainability—Welfare States Centrally Ensure National Food Security}

The measure "Food Dialogue" aims to involve all actors along the value chain, in order to enhance the supply with local food. In the first scenario, politics-as the leading actor in the food system-should engage in the dialog. However, this does not happen or does not work as intended, as the broad participation of consumers and other actors is missing in this scenario. The state makes decisions and is not willing to involve anyone else. Furthermore, the state would decide if a dialog takes place and with whom. The measure follows a bottom-up approach by nature and, thus, does not fit well in the world described by Scenario 1.

The "Market Basket for Local Food" brings together local supply and demand for local products of different stakeholders (e.g., communal kitchen chefs with farmers). It further aims to shift the consumption of food toward national dietary recommendations. As the state is in charge in this scenario, this measure can be easily pursued through the coordinated administration and overall perspective driving local food circles.

The "Farmer Markets 2.0" advance to become food hubs. The dimensions timing and location are adapted to provide better accessibility to food. However, as the consumer does not have an active role in this scenario and does not seek contact with the food producers, there is also no need to know where the food comes from. This will result in less success of this measure in Scenario 1. Another possibility is that the farmer's market gains another focus, away from the notion of buying directly from the producer toward buying local products without personal contact.

The measure "Open Food Labs" enables local food innovations and provides a testbed for farmers or start-ups to create new products for local value chains. As this scenario is ruled by the state, the actors of the value chain have no intrinsic motivation to bring forth new ideas. The food system is managed by the state and the food chain actors would not be rewarded for their own ideas. To trigger innovations, the state brings governmental incentive systems to life.

The "Food Policy Council", in contrast to the "Food Dialogue", follows a shared vision and goals for the urban food policy. This measure is feasible in the context of this scenario, as the state is the driving force behind the council and only a few decisions are top-down. At the same time, the Food Policy Council would only allow and support those measures which are in line with the national strategy for the food system. On one hand, this implies that decisions are made from a systematic top-down approach, taking into consideration the trade-offs and interactions between all elements of the food system. On the other hand, this structure is less susceptible to bottom-up initiatives and innovations.

The sixth measure, the "Online Metafinder", aims to help consumers to easily access local products. Information concerning the availability, accessibility, and the indication of origin is available through a meta-online platform. This measure fits into Scenario 1 , as the state can influence the content and use the tool to guide the purchasing behavior of consumers. The state-driven dissemination of this measure further assists to anchor this tool in consumer everyday use. Consequently, this will further increase the distribution.

\subsection{Scenario 2: Society Drives Sustainability—Consumers Enjoy a Green and Healthy Lifestyle}

In the second scenario, it is not necessary that politics initiate a "Food Dialogue", as the stakeholders are already highly connected and share the debate on local food topics. Thus, the coordination of the local food value chain is already exercised between the actors, on an informal basis. Society is informed and concerned about food topics. Therefore, if participative food events are offered, people attend and take the chance to get better educated and exchange information on new arising topics in the agri-food sector.

The measure "Market Basket for Local Food" fits into Scenario 2, as consumers are health-conscious and follow a sustainable diet. Consequently, the demand for local food is the highest under this scenario. Higher prices for local food are accepted by the consumers, as a change in values has taken place in society. 
The measure "Farmer Markets 2.0" would be very suitable for this scenario. As the consumer is very interested in connecting with the producers of their food, all possibilities of direct access to products will be accepted and further improved. Under this scenario, different approaches to connect consumers with producers of agricultural commodities can bear fruit.

"Open Food Labs" fit into this scenario, as participation is a crucial element of society. Agri-food stakeholders can develop local sustainable food products in food labs. Many startups, entrepreneurs, and farmers exist, who experiment with new products. In addition, consumers are very receptive to new local products. Producers tend to confine themselves to a limited geographical market. By doing so, they can use local resources, avoid transport, meet the specific needs of the local community, and engage people in participating in their businesses.

The "Food Policy Council" is widely accepted. People value this institutionalized measure, as it represents a systemic approach to address bottom-up food activities and top-down food plans. Thus, it can play an important role in the communication between the different actors within the agri-food value chain. Civil society is open to further political support, and this measure supports the exchange between agri-food stakeholders.

The "Online Metafinder" also fits into this scenario, as it supports the interests of consumers. They are highly conscious consumers, with regard to local produce and health aspects. The tool, in Scenario 2, will be configured to be used by many providers and consumers simultaneously. The local focus will be the main restriction of the search, in order to not provide too many results for the searched products. Hence, accessibility has to be very high from both ends of the value chain.

\subsection{Scenario 3: $\mathrm{A} \mathrm{CO}_{2}$ Currency and Retailers Dominate Trade and Consumption-In a Globalized World, Markets and Technologies Ensure Prosperity for Top Performers}

Retailers are the drivers of the "Food Dialogue", and conduct conversations for their own interest with the members of the food value chain. Therefore, they feel the need to act and to take the lead in the discussion to promote their own interests. The dialogs take place for different purposes than in the other scenarios. The need to coordinate with all actors along the value chain and use platforms for the exchange is driven by the implementation of $\mathrm{CO}_{2}$ currency. Other food value chain actors are not the ones to set the agenda for the food supply. In summary, the "Food Dialogue" enables a certain degree of exchange, which is of primary advantage to the retailers.

The "Market Basket for Local Food" and the "Farmer Markets 2.0" do not fit into this scenario, as local food products are only sold on a very small scale-and, rather, for marketing purposes-while most food is produced and sourced globally. Consumers value a great variety of food over the year and are not willing to renounce local food consumption. Overall, food prices are rather low. The willingness to pay more for food arises from quality considerations and for premium products. There is little awareness in society that sustainable products are more expensive in the production process.

"Open Food Labs" will not be a successful measure, as retailers dominate the food value chains and bottom-up food innovations cannot compete with the global food production regime. Unified high quantities are managed more efficiently than individual production in small batches. The promotion of food products from small-scale farmers or food start-ups is not important to retailers. Rather, retailers manage the joint innovation with consumers or farmers, and take the full advantage of it.

The measure "Food Policy Council" fits into this scenario, as the council can support an international plan for the global food supply, which is influenced, to a great extent, by retailers. Therefore, the FPC functions as a participatory instrument and is dominated by the interest of large-scale retailers. Only selected stakeholders are invited to participate in the council, and retailers decide upon whom to invite. This reflects the situation of highly consolidated structures within the food value chain. Large retailers and processing companies hold a high market share and dominate the value chain. 
The "Online Metafinder" will not fit into this scenario, as consumers do not value local food products. Retailers use the tool mainly for marketing purposes, in order to promote specific product categories in the upper price segment. In contrast to Scenario 2 , the platform must be designed toward a limited outreach.

\subsection{Robustness Check of the Measures in the Three Scenarios}

The robustness of the measures is an indication of their feasibility in more than one scenario. For example, if a measure is feasible in all scenarios, it is robust and, therefore, the recommendation for its implementation is high. The measure with the highest robustness of the six examined ones was the "Food Policy Council", followed by the "Online Metafinder". This implies that it is recommendable to implement these measures in local food systems, as they will most likely be successful in any future scenario. Other measures, such as "Open Food Labs", were less robust against alternative futures. Therefore, their implementation will not be equally successful in all the scenarios. As explained in Section 4 , the success of a measure depends on its design. There might be a need to adapt a measure to different framework conditions. For example, in Scenario 2, the "Online Metafinder" must be designed toward utilization by many stakeholders at many stages of the value chainespecially for producers, processors, and consumers-whereas, under Scenario 3, the layout must be adapted toward use by a few stakeholders that offer local food, with many more stakeholders requesting use but, overall, in a smaller setting compared with the other scenarios.

\subsection{Location of the Measures within the Food System}

The six measures from the road mapping process were located within the framework of the food system (see Figure 2). This assisted in visualizing the most likely addressed stages of the value chain or dimensions of the food system. We also visualized the coverage of the scenario description along the stages of the value chain, in order to determine that both approaches worked within this holistic picture (see Figure 3). Simultaneously, it enabled the identification of points not yet taken into consideration for the further implementation of measures. The measure "Food Dialogues" addresses many dimensions within the food system; namely, socio-economic, intellectual, and political ones. It was designed to bring together stakeholders from all steps of the value chain.

The local "Food Policy Council" (FPC) is a more institutionalized measure, which supplements the Food Dialogues. The FPC meets on a regular basis with committed stakeholders from various steps along the value chain. This enables the development of recommendations for targeted interventions, with focus on special points of interest within the food system. Compared with the Food Dialogue, the outcome of the FPC is more target-oriented toward a specific challenge within the food system and develops concrete actions, whereas the Food Dialogue takes place on a higher level of abstraction. Therefore, depending on the foreseen impact area, the FPC addresses the whole food system, but takes a thematic focus.

The "Market Basket for Local Food" targets the food production stage of the value chain, as well as the purchase of food directly from the end consumer or businesses processing food for immediate consumption. As the availability check and price information of food products are prominent features, the economic dimension is the most important one in this measure.

The "Online Metafinder" mainly addresses the consumer stage and provides an overview of local products. This measure can be hosted by the private sector or local public authorities; in the latter case, the political dimension plays a major role.

"Open Food Labs" correspond to the production stage of the value chain, and aim to equip farmers with infrastructure to test ideas and develop new products. Depending on the innovation, the processing stage of the value chain is targeted by this measure as well.

"Farmer Markets 2.0" addresses the retail and consumption stages of the value chain. Depending on the concrete implementation of updated farmer's markets, the focus is also 
on the social dimension, making agricultural production more visible to consumers and integrating the direct purchase of food into a modern lifestyle.

\section{Discussion}

The present paper aimed to test the robustness of measures for local agri-food value chains within the framework of European agri-food scenarios. The recent efforts to shorten food value chains demonstrate the importance of investigating these approaches within the whole food system. On one hand, regional and local supply can only provide a certain proportion of the food demand while, on the other hand, local food systems are embedded in a larger network of global trends and developments, which can have a significant impact on the configuration of local food supplies. In Section 6, we discuss the findings at the level of the three scenarios.

\subsection{Scenario 1: Policy Secures Sustainability-Welfare States Centrally Ensure National Food Security}

Centralized structures in agriculture managed by the state are described in Scenario 1. Recent developments have shown a tendency toward this development; for example, a feasibility study on governmental digital data platforms for agriculture in Germany has been conducted [79].

The "Market Basket for Local Food" supports the management of a healthy local food supply, by tracking local food sources in a target region in relation to national food recommendations. In this way, it can be aligned with SDG 2, which calls for an improved nutrition provision [80]. If more local food is consumed, this leads to more seasonal products in food supply, which can mean a greater nutritional value, due to less storage and optimized harvesting times [81-83]. Besides health, nutritional, and economic considerations, local food systems offer public benefits, such as the preservation of farmland in urbanizing areas, as well as the conservation of genetic diversity or the environment $[39,84]$.

To fully reap the benefits of "Open Food Labs", the measure must be targeted from both sides of the value chain. Innovators need the right framework conditions to be able to create new products. If the state puts too many regulations into place in Scenario 1, and companies are not confident that they can take the full economic advantage of their businesses, it is less likely that new local products will be developed. At the same time, the value chain-stage consumer is susceptible to local and regional products. The connection between these ends can be drawn by the right marketing strategy; Steenkamp and Jong [85], for example, stated that local firms should "compete on the local cultural relevance" of their products. In addition, health aspects $[86,87]$ and the feeling of belonging to a local community and support of the local economy lead consumer decisions to buy local products [88].

\subsection{Scenario 2: Society Drives Sustainability—Consumers Enjoy a Green and Healthy Lifestyle}

Under this scenario, the measure "Farmer Markets 2.0", as well as initiatives directly connecting the consumer and the producer, are likely to be successful. Food co-ops, solidarity agriculture, or self-gardening approaches with different levels of participation and interaction among farmers and consumers are dominant in a sustainability-oriented society [89]. The reasons for buying local products are manifold; for example, consumers rate them as a "more environmentally and climate friendly alternative", or as "fresher, safer and healthier" [89].

The reduction of transport distance can be effective to reduce $\mathrm{CO}_{2}$ emissions for certain products [33]. In addition, a comparative analysis of tomatoes produced in Austria, Italy, and Spain demonstrated the advantages, in terms of emissions reductions, when consuming seasonal products [90]. In contrast, when integrating other indicators for resource-efficient production, Kreidenweis et al. [15] found that the optimal production site should be determined for individual agricultural products but, in general, commodities should be imported from regions where the yields are very high. Kastner et al. [20] revealed that natural endowments, as well as land management, contribute to closing yield gaps in 
highly efficient regions. In line with that, a Swedish study concluded that the effect on the reduction of greenhouse gas emissions due to eating seasonal vegetables is limited when considering the whole food sector. This finding can be encouraged by the minor percentage of emissions caused by vegetable production [91].

To foster meaningful cooperation between the different actors along the food value chain and to address their heterogeneity, the "Food Policy Council" can be used as a formalized instrument. There are different behavioral factors influencing the collaboration in agri-food value chains [92]. Dania et al. [92] pointed out ten key behavioral factors; "Joint Efforts, Sharing Activities, Collaboration Value, Adaptation, Trust, Commitment, Power, Continuous Improvement, Coordination and Stability". It might be beneficial to address these factors in an institutionalized format, such as a Food Policy Council. Nevertheless, the measure can be criticized in this scenario, as the combination of top-down and bottom-up approaches might not address the pure bottom-up convention in this future world defined by active and engaged consumers.

In this second scenario, the demand for new and innovative technologies is very high and quite different from the other two scenarios. As many producers and processors are communicating with many consumers, requirements for data exchange are different from those where more consolidation leads to fewer actors at the producer side. For example, information and communication technologies (ICT) could assist in direct sales to consumers through social media and smart solutions [93].

The "Online Metafinder" will be successful in Scenario 2, due to the different network effects. In general, network theory suggests that the bigger the network, the more advantages it brings to users [94].

\subsection{Scenario 3: $\mathrm{ACO}_{2}$ Currency and Retailers Dominate Trade and Consumption-In a Globalized World, Markets and Technologies Ensure Prosperity for Top Performers}

In this scenario, global markets dominate the food supply. "Farmer Markets 2.0" only operate in niches. Farmers will become big companies, as the upcoming ICT will require high investments and lead to further structural changes in agriculture [93].

The willingness to pay a higher price for ecosystem-friendly products is very low in this scenario. As has been shown in the literature, sustainability labels comprising environmental and ethical aspects, "currently do not play a major role in consumers' food choice, and future use of these labels will depend on the extent to which consumers' general concern about sustainability can be turned into actual behaviour" [95].

The "Online Metafinder" is not successful in this scenario, due to the high market power of retailers and their international outreach, which was already evident more than two decades ago [96,97]. The high market share of retailers and processing companies can lead to unfair trading practices $[97,98]$.

\section{Conclusions and Outlook}

This study compared two different foresight approaches. To the best of our knowledge, this is the first study comparing global food scenarios with local food measures. However, there are other studies focused on the combination of global food scenarios and technology road mapping [22-27]. Focusing on specific technological areas and developing both foresight approaches in one project, we attempted to use existing scenarios and set the measures from the local roadmap in an international future context. The objective of this study was to investigate whether the local measures are still viable in the context of global scenarios. To do this, we used a robustness scale and a narrative/storytelling approach which allowed for obtaining deeper insights into how global food scenarios may influence local food measures. The results of this study suggest that it can provide additional value to transfer local strategy papers to the broader context of European scenarios. The second scenario was the one with the greatest awareness among the population, being able to participate as citizens while, at the same time, caring about what happens directly in their environment. This development within Scenario 2 goes hand-in-hand with the promotion of local food systems and explains the well-matched measures. Nevertheless, all three 
scenarios describe possible futures and are, thus, equally probable. We found that the Food Policy Council was the most robust, in the sense that it is likely to be applicable in all of the different scenarios. Our research underlines the importance of embedding local initiatives and measures into a bigger framework, and derives the consequences of future developments based on these local actions. The current study was limited to the consideration of measures in one city region. To derive further insights, measures from more example regions could be set in the context of the European scenarios on the agri-food sector for 2035. However, for the considered region, this assessment served to evaluate the measures from a more general future perspective. This can help local decision makers to be better informed, regarding strategic local food decisions.

In addition, it can be highlighted that this study addressed different levels of foresight approaches. Both methods aimed to point out signals for change at an early stage of the innovation cycle, in order to prepare actors involved accordingly for uncertainties. They invite the actors to deal with potential future developments; however, the approach is different for each method. The scenario method attempts to illustrate the interactions of different factors and describes an end-state, which is reflected in the detailed description of developments. The three scenarios focus on the European food sector, considering its policies, industries, and research sector but, concurrently, they also address the global perspective, due to the high interconnection of agricultural trade embedded in complex value chains. Therefore, the scenarios describe alternative future developments, while a road map shows a pathway toward a specific goal. Road mapping outlines a development path, visualizes it and, thus, prepares the participants for these developments. In addition, the chosen road mapping approach offers stakeholders the opportunity to visualize transformative pathways toward a more local food supply. Hence, the roadmap for the transition of the city region food system of Graz takes a local perspective, aimed at enhancing the local food supply of an urban region. The combination of the two approaches allowed us to show that a framework at the European level can be applied to the local context. This highlighted the importance of thinking in global terms, due to the magnitude of connections in the agri-food sector while, at the same time, acting locally to make food systems more resilient from a bottom-up perspective (e.g., Glocalization). To address local challenges, a systemic approach has to be combined with specific knowledge of the local conditions.

In innovation system theory, attention is paid to taking the whole system into consideration. Likewise, research within the agri-food domain can take advantage of this procedure [99]. Warnke et al. [100] stressed the importance of even widening the focus toward new actors and institutions in the food system and increasingly considering social innovations.

The measures presented were derived with respect to the target food region Graz and its surrounding districts. Therefore, they may be less relevant to other food systems, due to their specific geographical characteristics and systemic dependencies. To transform local food systems in a desired direction, it is thus necessary to understand their transformative capacities. This involves a thorough analysis at the system level. For instance, depending on local framework conditions, each food system has its own limitations toward the closest possible distance between food producers and consumers.

Further studies could target the specific opportunities of local food systems, in order to foster biodiversity. It is important to integrate biodiversity in local food value chains as food production depends on the presence of biodiversity while, at the same time, food production offers great opportunities for the promotion of biodiversity. Local biodiversity has especially received more attention in scientific discussions, and is seen as equally important as the effects on biodiversity on a global scale [101]. This could be carried out through the integration of biodiversity at the level of individual measures; this means to investigate whether certain measures already set in the roadmap would be favorable, neutral, or detrimental to biodiversity. 
Another option would be focus on ecologization in different scenarios, in order to enrich the road map with additional measures. For instance, one could investigate the effects of ecologization of agriculture on the production of food under the different scenarios.

The combination of these two foresight approaches makes it possible to make decisions toward certain measures, or the prioritization of measures could be conducted. In the case of limited resources, measures should be implemented which are robust in more than one possible future. Furthermore, our approach is transferable to other regions, concerning the applied method. In addition, the scenarios, with their specific content, can be used in combination with our method in other European regions.

Author Contributions: Conceptualization, A.V.-S., H.D., B.M., E.D. and S.B.; methodology, A.V.-S., H.D., B.M., E.D. and S.B.; writing-review and editing, A.V.-S., H.D., B.M., E.D., E.B. and S.B. All authors have read and agreed to the published version of the manuscript.

Funding: Parts of this research have received funding from the European Union's Horizon 2020 research and innovation program under grant agreement No 817683.

Conflicts of Interest: The authors declare no conflict of interest.

\section{References}

1. European Commission. Food 2030 Pathways for Action: Research and Innovation Policy as a Driver for Sustainable Healthy and Inclusive Systems; European Commission: Brussels, Belgium, 2020.

2. Garnett, T.; Appleby, M.C.; Balmford, A.; Bateman, I.J.; Benton, T.G.; Bloomer, P.; Burlingame, B.; Dawkins, M.; Dolan, L.; Fraser, D.; et al. Agriculture. Sustainable intensification in agriculture: Premises and policies. Science 2013, 341, 33-34. [CrossRef]

3. Jurgilevich, A.; Birge, T.; Kentala-Lehtonen, J.; Korhonen-Kurki, K.; Pietikäinen, J.; Saikku, L.; Schösler, H. Transition towards Circular Economy in the Food System. Sustainability 2016, 8, 69. [CrossRef]

4. Willett, W.; Rockström, J.; Loken, B.; Springmann, M.; Lang, T.; Vermeulen, S.; Garnett, T.; Tilman, D.; DeClerck, F.; Wood, A.; et al. Food in the Anthropocene: The EAT-Lancet Commission on healthy diets from sustainable food systems. Lancet 2019, 393, 447-492. [CrossRef]

5. Caron, P.; Ferrero, Y.; de Loma-Osorio, G.; Nabarro, D.; Hainzelin, E.; Guillou, M.; Andersen, I.; Arnold, T.; Astralaga, M.; Beukeboom, M.; et al. Food systems for sustainable development: Proposals for a profound four-part transformation. Agron. Sustain. Dev. 2018, 38, 41. [CrossRef] [PubMed]

6. Pereira, L.M.; Drimie, S.; Maciejewski, K.; Tonissen, P.B.; Biggs, R.O. Food System Transformation: Integrating a Political-Economy and Social-Ecological Approach to Regime Shifts. Int. J. Environ. Res. Public Health 2020, 17, 1313. [CrossRef] [PubMed]

7. Farrell, P.; Thow, A.M.; Wate, J.T.; Nonga, N.; Vatucawaqa, P.; Brewer, T.; Sharp, M.K.; Farmery, A.; Trevena, H.; Reeve, E.; et al. COVID-19 and Pacific food system resilience: Opportunities to build a robust response. Food Secur. 2020, 12, 783-791. [CrossRef]

8. OECD. OECD-FAO Agricultural Outlook 2020-2029; OECD: Paris, France, 2020; ISBN 9789264317673.

9. Béné, C. Resilience of local food systems and links to food security-A review of some important concepts in the context of COVID-19 and other shocks. Food Secur. 2020, 12, 805-822. [CrossRef] [PubMed]

10. Thilmany, D.; Canales, E.; Low, S.A.; Boys, K. Local Food Supply Chain Dynamics and Resilience during COVID-19. Appl. Econ. Perspect. Policy 2021, 43, 86-104. [CrossRef]

11. Perdana, T.; Chaerani, D.; Achmad, A.L.H.; Hermiatin, F.R. Scenarios for handling the impact of COVID-19 based on food supply network through regional food hubs under uncertainty. Heliyon 2020, 6, e05128. [CrossRef] [PubMed]

12. Dwivedi, S.L.; van Lammerts Bueren, E.T.; Ceccarelli, S.; Grando, S.; Upadhyaya, H.D.; Ortiz, R. Diversifying Food Systems in the Pursuit of Sustainable Food Production and Healthy Diets. Trends Plant Sci. 2017, 22, 842-856. [CrossRef]

13. Herrero, M.; Thornton, P.K.; Power, B.; Bogard, J.R.; Remans, R.; Fritz, S.; Gerber, J.S.; Nelson, G.; See, L.; Waha, K. Farming and the geography of nutrient production for human use: A transdisciplinary analysis. Lancet Planet. Health 2017, 1, e33-e42. [CrossRef]

14. European Commission. Farm to Fork Strategy: For a Fair, Healthy and Environmentally-Friendly Food System; European Commission: Brussels, Belgium, 2020.

15. Kreidenweis, U.; Lautenbach, S.; Koellner, T. Regional or global? The question of low-emission food sourcing addressed with spatial optimization modelling. Environ. Model. Softw. 2016, 82, 128-141. [CrossRef]

16. Avetisyan, M.; Hertel, T.; Sampson, G. Is Local Food More Environmentally Friendly? The GHG Emissions Impacts of Consuming Imported versus Domestically Produced Food. Environ. Resour. Econ. 2014, 58, 415-462. [CrossRef]

17. Jia, S. Local Food Campaign in a Globalization Context: A Systematic Review. Sustainability 2021, 13, 7487. [CrossRef]

18. Schmitt, E.; Galli, F.; Menozzi, D.; Maye, D.; Touzard, J.-M.; Marescotti, A.; Six, J.; Brunori, G. Comparing the Sustainability of Local and Global Food Products in Europe. J. Clean. Prod. 2017, 165, 346-359. [CrossRef]

19. MacFal, J.; Massey Lelekacs, J.; LeVasseur, T.; Moore, S.; Walker, J. Toward resilient food systems through increased agricultural diversity and local sourcing in the Carolinas. J. Environ. Stud. Sci. 2015, 5, 608-622. [CrossRef] [PubMed] 
20. Kastner, T.; Erb, K.-H.; Haberl, H. Rapid growth in agricultural trade: Effects on global area efficiency and the role of management. Environ. Res. Lett. 2014, 9, 34015. [CrossRef]

21. Kissinger, M.; Sussmann, C.; Dorward, C.; Mullinix, K. Local or global: A biophysical analysis of a regional food system. Renew. Agric. Food Syst. 2019, 34, 523-533. [CrossRef]

22. Saritas, O.; Aylen, J. Using scenarios for roadmapping: The case of clean production. Technol. Forecast. Soc. Chang. 2010, 77, 1061-1075. [CrossRef]

23. Cagnin, C.; Könnölä, T. Global foresight: Lessons from a scenario and roadmapping exercise on manufacturing systems. Futures 2014, 59, 27-38. [CrossRef]

24. Cheng, M.N.; Wong, J.W.; Cheung, C.F.; Leung, K.H. A scenario-based roadmapping method for strategic planning and forecasting: A case study in a testing, inspection and certification company. Technol. Forecast. Soc. Chang. 2016, 111, 44-62. [CrossRef]

25. Hussain, M.; Tapinos, E.; Knight, L. Scenario-driven roadmapping for technology foresight. Technol. Forecast. Soc. Chang. 2017, 124, 160-177. [CrossRef]

26. Lee, C.; Song, B.; Park, Y. An instrument for scenario-based technology roadmapping: How to assess the impacts of future changes on organisational plans. Technol. Forecast. Soc. Chang. 2015, 90, 285-301. [CrossRef]

27. Hansen, C.; Daim, T.; Ernst, H.; Herstatt, C. The future of rail automation: A scenario-based technology roadmap for the rail automation market. Technol. Forecast. Soc. Chang. 2016, 110, 196-212. [CrossRef]

28. Berner, S.; Derler, H.; Rehorska, R.; Pabst, S.; Seebacher, U. Roadmapping to Enhance Local Food Supply: Case Study of a City-Region in Austria. Sustainability 2019, 11, 3876. [CrossRef]

29. Moller, B.; Voglhuber-Slavinsky, A.; Dönitz, E. Three Scenarios for Europe's Food Sector in 2035; Fraunhofer ISI: Karlsruhe, Germany, 2020.

30. Dijkstra, L.; Poelman, H. Cities in Europe: The New OECD-EC Definition, 2012. Available online: https://ec.europa.eu/regional_ policy / sources/docgener/focus/2012_01_city.pdf (accessed on 19 May 2021).

31. Wegscheider-Pichler, A.; Prettner, C.; Lamei, N. Wie Geht's Österreich? 2020: Indikatoren und Analysen Sowie COVID-19-Ausblick; Statistik Austria: Wien, Austria, 2020.

32. Majumder, A.; Ray, R. National and subnational purchasing power parity: A review. Decision 2020, 47, 103-124. [CrossRef]

33. Pradhan, P.; Kriewald, S.; Costa, L.; Rybski, D.; Benton, T.G.; Fischer, G.; Kropp, J.P. Urban Food Systems: How Regionalization Can Contribute to Climate Change Mitigation. Environ. Sci. Technol. 2020, 54, 10551-10560. [CrossRef]

34. Kriewald, S.; Pradhan, P.; Costa, L.; Ros, A.G.C.; Kropp, J.P. Hungry cities: How local food self-sufficiency relates to climate change, diets, and urbanisation. Environ. Res. Lett. 2019, 14, 94007. [CrossRef]

35. Greco, L.; Kolodinsky, J.; Sitaker, M.; Chase, L.; Conner, D.; Smith, D.; Estrin, H.; van Soelen Kim, J. Farm Fresh Food Boxes: Relationships in Value Chain Partnerships. J. Agric. Food Syst. Community Dev. 2020, 9, 1-17. [CrossRef]

36. Palmer, A.; Santo, R.; Berlin, L.; Bonanno, A.; Clancy, K.; Giesecke, C.; Hinrichs, C.; Lee, R.; McNab, P.; Rocker, S. Between Global and Local: Exploring Regional Food Systems from the Perspectives of Four Communities in the U.S. Northeast. J. Agric. Food Syst. Community Dev. 2017, 7, 187-205. [CrossRef]

37. Augère-Granier, M.-L. Short Food Supply Chains and Local Food Systems in the EU; European Parliamentary Research Service, EPRS: Brussels, Belgium, 2016.

38. Kneafsey, M.; Venn, L.; Schmutz, U.; Balázs, B.; Trenchard, L.; Eyden-Wood, T.; Bos, E.; Sutton, G.; Blackett, M. Short food supply chains and local food systems in the EU. A state of play of their socio-economic characteristics. JRC Sci. Policy Rep. 2013, $123,129$.

39. Martinez, S.; Hand, M.; da Pra, M.; Pollack, S.; Ralston, K.; Smith, T.; Vogel, S.; Clark, S.; Lohr, L.; Low, S.; et al. Local Food Systems: Concepts, Impacts, and Issues; Diane Publishing: Collingdale, PA, USA, 2010.

40. Hendrickson, M.; Massengale, S.H.; Weber, C. Introduction to Local Food Systems; Diane Publishing: Collingdale, PA, USA, 2015.

41. Westhoek, H.; Ingram, J.; van Berkum, S.; Hajer, M. Food Systems and Natural Resources; United Nations Environment Programme: Nairobi, Kenya, 2016; ISBN 978-92-807-3560-4.

42. FAO. Sustainable Food Systems: Concept and Framework; FAO: Rome, Italy, 2018.

43. Ericksen, P.J. Conceptualizing food systems for global environmental change research. Glob. Environ. Chang. 2008, 18, 234-245. [CrossRef]

44. Gaitán-Cremaschi, D.; Klerkx, L.; Duncan, J.; Trienekens, J.H.; Huenchuleo, C.; Dogliotti, S.; Contesse, M.E.; Rossing, W.A.H. Characterizing diversity of food systems in view of sustainability transitions. A review. Agron. Sustain. Dev. $2019,39,1$. [CrossRef] [PubMed]

45. Mausch, K.; Hall, A.; Hambloch, C. Colliding paradigms and trade-offs: Agri-food systems and value chain interventions. Glob. Food Secur. 2020, 26, 100439. [CrossRef]

46. Vermeulen, S.J.; Campbell, B.M.; Ingram, J.S. Climate Change and Food Systems. Annu. Rev. Environ. Resour. 2012, 37, 195-222. [CrossRef]

47. Godfray, H.C.J.; Crute, I.R.; Haddad, L.; Lawrence, D.; Muir, J.F.; Nisbett, N.; Pretty, J.; Robinson, S.; Toulmin, C.; Whiteley, R. The future of the global food system. Philos. Trans. R. Soc. Lond. B Biol. Sci. 2010, 365, 2769-2777. [CrossRef]

48. Luo, J.; Ji, C.; Qiu, C.; Jia, F. Agri-Food Supply Chain Management: Bibliometric and Content Analyses. Sustainability 2018, 10, 1573. [CrossRef] 
49. Bukeviciute, L.; Dierx, A.H.; Ilzkovitz, F. The Functioning of the Food Supply Chain and Its Effect on Food Prices in the European Union; European Commission Directorate-General for Economic and Financial Affairs Publications: Brüssel, Belgium, 2009; ISBN 978-92-79-11261-4.

50. Stanco, M.; Nazzaro, C.; Lerro, M.; Marotta, G. Sustainable Collective Innovation in the Agri-Food Value Chain: The Case of the "Aureo" Wheat Supply Chain. Sustainability 2020, 12, 5642. [CrossRef]

51. Ricciotti, F. From value chain to value network: A systematic literature review. Manag. Rev. Q. 2020, 70, 191-212. [CrossRef]

52. FAO. Developing Sustainable Food Systems and Value Chains for CSA. Available online: http://www.fao.org/climate-smartagriculture-sourcebook/production (accessed on 16 December 2020).

53. Sheane, R.; McCosker, C.; Royston, S. Food System Framework: A Focus on Food Sustainabilbity; IFST: London, UK, 2008.

54. Deloitte. The Food Value Chain: A Challenge for the Next Century; Deloitte: London, UK, 2013.

55. Phaal, R.; Farrukh, C.J.; Probert, D.R. Technology roadmapping-A planning framework for evolution and revolution. Technol. Forecast. Soc. Chang. 2004, 71, 5-26. [CrossRef]

56. Lee, S.K.; Mogi, G.; Kim, J.W. Energy technology roadmap for the next 10 years: The case of Korea. Energy Policy 2009, 37, 588-596. [CrossRef]

57. Gallegos Rivero, A.R.; Daim, T. Technology roadmap: Cattle farming sustainability in Germany. J. Clean. Prod. 2017, 142, 4310-4326. [CrossRef]

58. Amer, M.; Daim, T.U. Application of technology roadmaps for renewable energy sector. Technol. Forecast. Soc. Chang. 2010, 77, 1355-1370. [CrossRef]

59. Phaal, R.; Muller, G. An architectural framework for roadmapping: Towards visual strategy. Technol. Forecast. Soc. Chang. 2009, 76, 39-49. [CrossRef]

60. Godet, M. Creating Futures. Scenario Planning as Strategic Management Tool; Economica: London, UK, 2001.

61. van Notten, P.W.; Rotmans, J.; van Asselt, M.B.; Rothman, D.S. An Updated Scenario Typology. Futures 2003, 35, 423-443. [CrossRef]

62. Schwartz, P. The Art of the Long View. Planning for the Future in an Uncertain World; Currency and Doubleday: New York, NY, USA, 1991; ISBN 0-471-97785-3.

63. van der Heijden, K. Scenarios. The Art of Strategic Conversation; Wiley: Chichester, UK, 1997; ISBN 0-471-96639-8.

64. Ringland, G. Scenarios in Public Policy; John Wiley \& Sons: Chichester, UK, 2002; ISBN 0470843837.

65. Ringland, G. Scenario Planning: Managing for the Future; John Wiley \& Sons: Chichester, UK, 1998; ISBN 0-471-97790-X.

66. Dönitz, E.J.; Schirrmeister, E. Foresight and Scenarios at Fraunhofer ISI. Probl. Eksploat. Maint. Probl. 2013, 4, 15-28.

67. Gabriel, J.; Warnke, P.; Schirrmeister, E.; Dönitz, E. Qualitative Szenarien als Tool des Organisationalen Lernens. In Strategische Vorausschau in der Politikberatung: Beiträge und Diskussionsergebnisse eines UBA-Fachgesprächs; Schnurr, M., Glockner, H., Eds.; Umweltbundesamt: Dessau-Roßlau, Germany, 2016; pp. 13-19.

68. Ringland, G. The role of scenarios in strategic foresight. Technol. Forecast. Soc. Chang. 2010, 77, 1493-1498. [CrossRef]

69. Dönitz, E. Effizientere Szenariotechnik durch Teilautomatische Generierung von Konsistenzmatrizen: Empirie, Konzeption, Fuzzy- und Neuro-Fuzzy-Ansätze, 1st ed.; Gabler: Wiesbaden, Germany, 2009; ISBN 978-3-8349-1668-6.

70. Wilkinson, A.; Kupers, R.; Mangalagiu, D. How plausibility-based scenario practices are grappling with complexity to appreciate and address 21st century challenges. Technol. Forecast. Soc. Chang. 2013, 80, 699-710. [CrossRef]

71. Wright, G.; Bradfield, R.; Cairns, G. Does the intuitive logics method-And its recent enhancements-Produce "effective" scenarios? Technol. Forecast. Soc. Chang. 2013, 80, 631-642. [CrossRef]

72. Moller, B.; Voglhuber-Slavinsky, A.; Dönitz, E.; Rosa, A. 50 Trends Influencing Europe's Food Sector by 2035; Fraunhofer ISI: Karlsruhe, Germany, 2019.

73. Spaniol, M.J.; Rowland, N.J. Defining scenario. Futures Foresight Sci. 2019, 1, e3. [CrossRef]

74. Vervoort, J.M.; Kok, K.; Beers, P.-J.; van Lammeren, R.; Janssen, R. Combining analytic and experiential communication in participatory scenario development. Landsc. Urban Plan. 2012, 107, 203-213. [CrossRef]

75. Dönitz, E.; Voglhuber-Slavinsky, A.; Moller, B. Agribusiness in 2035-Farmers of the Future; Fraunhofer ISI: Karlsruhe, Germany, 2020.

76. Feenstra, G. Creating space for sustainable food systems: Lessons from the field. Agric. Hum. Values 2002, 19, 99-106. [CrossRef]

77. Clayton, M.L.; Frattaroli, S.; Palmer, A.; Pollack, K.M. The role of partnerships in U.S. Food Policy Council policy activities. PLoS ONE 2015, 10, e0122870. [CrossRef]

78. Ashby, J.; Heinrich, G.; Burpee, G.; Remington, T.; Wilson, K.; Quiros, C.A.; Aldana, M.; Ferris, S. What farmers want: Collective capacity for sustainable entrepreneurship. Int. J. Agric. Sustain. 2009, 7, 130-146. [CrossRef]

79. Bartels, N.; Dörr, J.; Fehrmann, J.; Gennen, K.; Groen, E.C.; Härtel, I.; Henningsen, J.; Herlitzius, T.; Jeswein, T.; Kunisch, M.; et al. Abschlussbericht Machbarkeitsstudie: Machbarkeitsstudie zu Staatlichen Digitalen Datenplattformen für die Landwirtschaft; IESE-Report Nr. 022.20/D.; Fraunhofer: Munich, Germany, 2020.

80. United Nations. Global Indicator Framework for the Sustainable Development Goals and Targets of the 2030 Agenda for Sustainable Development; A/RES/71/313; United Nations: New York, NY, USA, 2017.

81. Remorini, D.; Tavarini, S.; Degl'Innocenti, E.; Loreti, F.; Massai, R.; Guidi, L. Effect of rootstocks and harvesting time on the nutritional quality of peel and flesh of peach fruits. Food Chem. 2008, 110, 361-367. [CrossRef] [PubMed] 
82. Raffo, A.; Leonardi, C.; Fogliano, V.; Ambrosino, P.; Salucci, M.; Gennaro, L.; Bugianesi, R.; Giuffrida, F.; Quaglia, G. Nutritional value of cherry tomatoes (Lycopersicon esculentum Cv. Naomi F1) harvested at different ripening stages. J. Agric. Food Chem. 2002, 50, 6550-6556. [CrossRef] [PubMed]

83. Ziv, C.; Fallik, E. Postharvest Storage Techniques and Quality Evaluation of Fruits and Vegetables for Reducing Food Loss. Agronomy 2021, 11, 1133. [CrossRef]

84. Peters, C.J.; Bills, N.L.; Wilkins, J.L.; Fick, G.W. Foodshed analysis and its relevance to sustainability. Renew. Agric. Food Syst. 2009, 24, 1-7. [CrossRef]

85. Steenkamp, J.-B.E.; de Jong, M.G. A Global Investigation into the Constellation of Consumer Attitudes toward Global and Local Products. J. Mark. 2010, 74, 18-40. [CrossRef]

86. Annunziata, A.; Mariani, A. Consumer Perception of Sustainability Attributes in Organic and Local Food. Recent Pat. Food Nutr. Agric. 2018, 9, 87-96. [CrossRef]

87. Birch, D.; Memery, J.; de Silva Kanakaratne, M. The mindful consumer: Balancing egoistic and altruistic motivations to purchase local food. J. Retail. Consum. Serv. 2018, 40, 221-228. [CrossRef]

88. Feldmann, C.; Hamm, U. Consumers' perceptions and preferences for local food: A review. Food Qual. Prefer. 2015, 40, 152-164. [CrossRef]

89. Warnke, P.; Dönitz, E.; Opitz, I.; Zoll, F.; Doernberg, A.; Specht, K.; Siebert, R.; Piorr, A.; Berges, R. Szenarien zur Zukunft der Nahrungsmittelversorgung: Chancen und Herausforderungen für Alternative Versorgungsnetzwerke; Fraunhofer-Institut für Systemund Innovationsforschung ISI: Karlsruhe, Germany, 2018.

90. Theurl, M.C.; Haberl, H.; Erb, K.-H.; Lindenthal, T. Contrasted greenhouse gas emissions from local versus long-range tomato production. Agron. Sustain. Dev. 2014, 34, 593-602. [CrossRef]

91. Röös, E.; Karlsson, H. Effect of eating seasonal on the carbon footprint of Swedish vegetable consumption. J. Clean. Prod. 2013, 59, 63-72. [CrossRef]

92. Dania, W.A.P.; Xing, K.; Amer, Y. Collaboration behavioural factors for sustainable agri-food supply chains: A systematic review. J. Clean. Prod. 2018, 186, 851-864. [CrossRef]

93. Poppe, K.; Wolfert, S.; Verdouw, C.; Renwick, A. A European Perspective on the Economics of Big Data. Farm Policy J. 2015, 12, 11-19.

94. Lee, S.M.; Kim, T.; Noh, Y.; Lee, B. Success factors of platform leadership in web 2.0 service business. Serv. Bus. 2010, 4, 89-103. [CrossRef]

95. Grunert, K.G.; Hieke, S.; Wills, J. Sustainability labels on food products: Consumer motivation, understanding and use. Food Policy 2014, 44, 177-189. [CrossRef]

96. Bell, R.; Davies, R.; Howard, E. The changing structure of food retailing in europe: The implications for strategy. Long Range Plan. 1997, 30, 853-861. [CrossRef]

97. European Commission. Report from the Commission to the European Parliament and the Council on Unfair Business-to-Business Trading Practices in the Food Supply Chain; European Commission: Brussels, Belgium, 2016.

98. European Commission. The Directive on UNFAIR TRADING PRACTICES in the Agricultural and Food Supply Chain; European Commission: Brussels, Belgium, 2019.

99. Hekkert, M.; Negro, S.; Heimeriks, G.; Harmsen, R.O.; Jong, S.D. Technological Innovation System Analysis A Manual for Analysts. 2011. Available online: https://www.semanticscholar.org/paper/Technological-Innovation-System-Analysis-Amanual-Hekkert-Negro/68e1abecbbe0da073c7e63d95dbb750f5d910024 (accessed on 19 May 2021).

100. Warnke, P.; Koschatzky, K.; Dönitz, E.; Zenker, A.; Stahlecker, T.; Som, O.; Cuhls, K.; Güth, S. Opening up the Innovation System Framework Towards New Actors and Institutions; Fraunhofer ISI Discussion Papers-Innovation Systems and Policy Analysis. No. 49, 2016. Available online: https://www.econstor.eu/handle/10419/129191 (accessed on 19 May 2021).

101. Hooper, D.U.; Adair, E.C.; Cardinale, B.J.; Byrnes, J.E.K.; Hungate, B.A.; Matulich, K.L.; Gonzalez, A.; Duffy, J.E.; Gamfeldt, L.; O'Connor, M.I. A global synthesis reveals biodiversity loss as a major driver of ecosystem change. Nature 2012, 486, 105-108. [CrossRef] 